\title{
Review Article \\ From Rural to Urban: Archaeological Research in the Periphery of Huari, Ayacucho Valley, Peru
}

\author{
Lidio M. Valdez ${ }^{1}$ and J. Ernesto Valdez ${ }^{2}$ \\ ${ }^{1}$ MacEwan University, Edmonton, AB, Canada \\ ${ }^{2}$ Universidad de Huamanga, Ayacucho, Peru \\ Correspondence should be addressed to Lidio M. Valdez; lidio9@yahoo.es \\ Received 12 July 2016; Accepted 16 October 2016; Published 13 February 2017 \\ Academic Editor: Benjamin Campbell
}

Copyright (C) 2017 Lidio M. Valdez and J. Ernesto Valdez. This is an open access article distributed under the Creative Commons Attribution License, which permits unrestricted use, distribution, and reproduction in any medium, provided the original work is properly cited.

\begin{abstract}
For hundreds upon hundreds of years, humans lived in small settlements where most individuals, if not all, were linked by kinship ties. Many of these villages were occupied for generations and thus their occupants had a strong connection to the place. The villages were politically and economically autonomous, yet they were connected with adjacent villages by means of barter and intermarriage. Within a relatively short period of time, centuries-long occupied small villages were left vacant and replaced by fewer but much larger settlements identified as cities. In contrast to the rural based villages, cities began to house much larger numbers of residents, who not only were unfamiliar with each other but also were mainly concerned with their own well-being. Recent archaeological research carried out in the immediate periphery of Huari provides crucial information that indicates that the growth of Huari paralleled the abandonment of rural villages apparently in the midst of increasing conflict. The rural settlement of Huaqanmarka was occupied for several centuries, yet it was abandoned within a short period of time simultaneously with the desertion of other adjacent settlements.
\end{abstract}

\section{Introduction}

The emergence of urban centers represents a significant departure from the previous centuries-old rural-oriented pattern $([1], 117)$. By their nature, urban centers are large and house populations in the thousands ([2], 527-528; [3], 11; [4], 310-311), most of whom are nonkin related and whose main activity is distant from agriculture. Instead, urban centers are occupied by bureaucrats specialized in a variety of activities that include state administration, merchants, and craft specialists, in addition to military and religious personnel. Additional important features of urban centers are that their residents are class divided and have different ethnic backgrounds. Ever since their initial establishment, cities continue thriving as an ever growing number of families arrive within their confines [4-8]. Archaeological research has shown that, in the distant past, cities arose for the first time only in a few regions ([9], 400; [10]), western central South America being one of them [11-13]. However, questions remain with regard to why and under what circumstances cities (and states) emerged in the first place [14-24]. Likewise, for the particular case of the Central Andes, what is still little understood are the reasons that triggered the abandonment of the small villages, occupied by generations, in order to embrace a totally new pattern of living.

Huari ${ }^{1}$ is one of the largest archaeological sites in western South America ([25], 122, [26], 131, [27], 1-2, [28], 93, [29], 81). Found in the Peruvian central highland valley of Ayacucho (Figure 1) [28, 30-39] and at an elevation that ranges between 2,500 and 2,900 $\mathrm{m}$ asl., Huari appears to have been initially established around the turn of the Common Era (CE) and began to rapidly grow about the year $550 \mathrm{CE}$ ([40], 20-21, 3637; [32]). During the following three centuries, the settlement experienced an unprecedented transformation; it became not only the single largest settlement of the Ayacucho Valley ${ }^{2}$, but also the most influential of the entire Central Andes ([28, 41], [40], 38; [37, 39]).

Researchers argue that this radical change at Huari occurred parallel to the establishment of a centralized political authority centered at the site, named the Wari State ([37], 


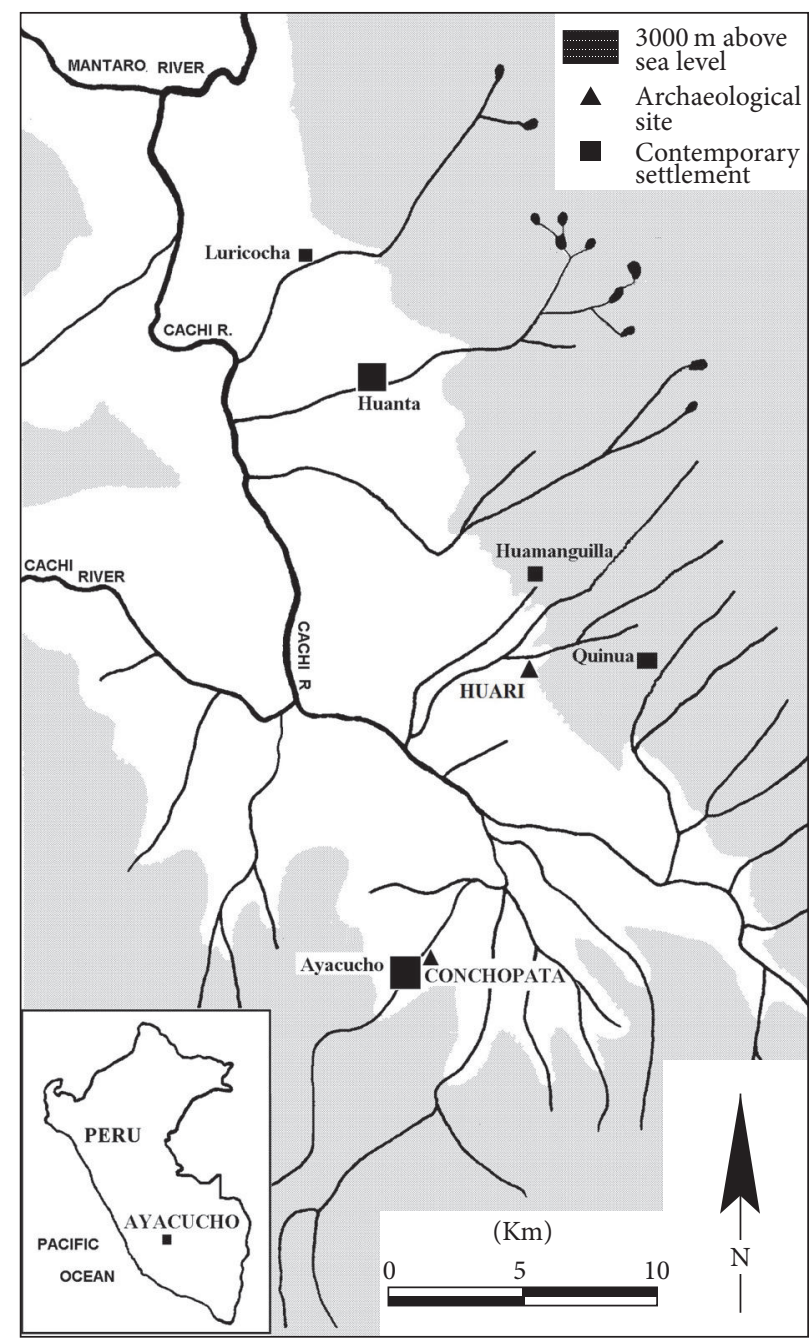

FIGURE 1: Map of location of Huari in relationship with other settlements of the Ayacucho Valley, in the Peruvian central highlands.

67; [42], 91; [38, 43-45]). This newly established political authority was able to reorganize its hinterland and thereafter began one of the most ambitious and unprecedented projects that the entire central western South America had ever witnessed, the establishment of political control over most of the Central Andes ([46]; [36], 14; [37], 68; [35], 115; [33], 374; [47], 93; [38], 79, 93; [29], 80; [13], 54]). In the newly conquered territories, a series of intrusive centers, displaying a foreign architectural style and associated with a ceramic style with roots in the Ayacucho Valley, emerged. These centers, such as Pikillaqta in the Cuzco region [48-50], have been identified as the provincial capitals established by the Wari administration [51, 52]. Within the archaeology of the Central Andes, the time during which the Wari State flourished is identified as the Middle Horizon period (ca. 550-1100 CE).

How and under what circumstances the city of Huari arose remain little known $([40], 20)$ largely due to the paucity of archaeological investigation at the site. Its enormous size $[25,32]$ and centuries of human occupation ([28], 186) make it also a challenging task to trace any evidence of earlier occupations that remain buried by later more complex structures. Site destruction has also severely modified surface evidence, as walls and at times entire structures have been demolished. Despite all these limitations, researchers have acknowledged Huari's unique position within the indigenous cultural development of the central Andean region; Huari signals the beginning of urban life in the Central Andes ([37], 68; [40], 38). Before Huari there were large centers in the Central Andes, some of which have been identified as "urban centers" (see $[11,36]$ ); however, as pointed out by Lumbreras ([40], 38), those so-called "urban centers" were organized around ceremonial centers. In contrast, with Huari the Central Andean region witnessed for the first time the appearance of a large center not only defended by massive walls but also occupied by a large population $[28,32]$ whose main activity was divorced from agriculture. Thus Huari housed specialists in craft production, in addition to state bureaucrats, merchants, and military and religious personnel. Nothing like this existed in the Central Andes before the Middle Horizon.

The aim of this report is to present and discuss new data coming from a site found in the immediate periphery of the 
ancient urban center of Huari. Recently an archaeological excavation was carried out on a hilltop found immediately to the west of the core area of Huari resulting in the discovery of evidence for intensive human occupation prior to the emergence of Huari [53]. This study demonstrates that, about the time Huari was to become the most important settlement of the central Andean region, the hilltop site of Huaqanmarka was deserted; its population appears to have been relocated elsewhere, likely to Huari. This field study provides concrete archaeological evidence that indicates that the growth of Huari paralleled the depopulation of its immediate hinterland. To contextualize the new archaeological evidence in a broader context, the reason(s) that triggered the abandonment of Huaqanmarka is also discussed.

\section{The Ancient Viñaqui, Huari}

Shortly after the Spanish conquest, Cieza de León travelled through the Peruvian central highlands on his way to the ancient capital of the Inka Empire, Cuzco. Cieza de León followed the Inka royal highway that crossed the Ayacucho Valley and while in the neighbourhood of the Wiñaq River (now Pongora River) observed some large and very old buildings, named Viñaqui, reportedly established long before the reign of the Inkas ([54], 207). Thus, if not the first, certainly ancient Viñaqui (currently Huari) is among the first ancient Andean settlements recorded in print. In spite of this relatively early account, Huari remained partially unknown until Peruvian archaeologist Julio C. Tello visited the site in 1931 ([26], 131; [55], 1; [38], 79). Unfortunately, Tello never published his visit, but the news captured the attention of other researchers ([56], 99; [57] 13; [58], 142-143), who quickly made the suggestion that the recently rediscovered site of Huari perhaps was the center for dispersion of the Tiahuanacoid art style ${ }^{3}$.

In 1946 Rowe, Collier and Willey ([25], 122) paid a brief visit to the site of Huari and acknowledged the enormous size of the site. Since the initial descriptions provided by Rowe, Collier, and Willey, efforts have been made to investigate Huari $[26,28,31,32,35,59-64]$. However, during the 1980s and part of the 1990s archaeological research at Huari and in the Ayacucho Valley in general was disrupted due to the guerrilla activities of the Shining Path. When finally research resumed in the Ayacucho Valley and Huari during the mid1990s [65-70], it became evident that the Andean Middle Horizon was better known from the provinces [71-74] than from its capital city, Huari.

Despite some notable efforts, particularly by Isbell [28, $31,32,63]$, the history of development and the manner by which Huari became the single largest and most influential city of the entire Central Andes remains little understood. In addition to the political unrest that prevented research, the lack of large-scale and long-term archaeological research at Huari is one of the chief reasons for the current state of knowledge. Moreover, a brief review of the archaeological studies carried out at Huari shows the strong preference of researchers for investigating the area with monumental architecture [31, 32, 60-64], leaving its immediate periphery untouched.
There can be little doubt that research of Huari's core area is necessary. Indeed, long term, an interdisciplinary approach has the potential to reveal aspects about, for instance, how people coped in an urban setting. At the same time, few will deny that the formation of a city, such as Huari, "can be understood only in relation to its hinterland" ([14], 18). Thus, in order to explain how and why Huari became the largest and most influential center of the entire Central Andes, it is vital to investigate the developments that occurred around the area where Huari arose. It must be acknowledged that previous surface studies in the immediate periphery of Huari already revealed the existence of several rural settlements established long before the Middle Horizon ([37], 5-7; [32], 175; [28], 190; [29], 81; see also [75, 76]). However, what role, if any, these settlements played in the development of Huari remains little explained. Likewise, it is uncertain how Huari's transformation into an urban center affected, directly or indirectly, these neighbouring settlements. Hence, the preMiddle Horizon Huarpa villages need to be investigated, particularly knowing that archaeological information for the period remains poor ([59], 309). In the following section, we present information coming from a small rural settlement found on the periphery of Huari that was occupied prior to the emergence of this great urban center but deserted as Huari began to grow.

\section{The Huaqanmarka Hilltop at the Periphery of Huari}

Previous surface research of the area immediate to the great urban center of Huari $[28,37,40,77]$ revealed the presence of several small settlements (Figure 2) that, according to surface ceramic findings, were initially established during the Early Intermediate period (hereafter EIP) (ca. 100 BCE$550 \mathrm{CE})$, with others perhaps even earlier ([28], 189). These include the site of Churukana found on a hilltop east of Huari ([37], 5; [28], 190), Vista Alegre found about $4 \mathrm{~km}$ west of Churukana and south of the core area of Huari $[28,77]$, and Chupapata (also called West Huarpa Community) located immediately to the west of the core area of Huari ([28], Figure 6; [77]; [40], Lam. 34). On the north edge of Huari, in the Sullu Cruz sector, Bennett [60] excavated his pit 4 and uncovered Huarpa ceramics that indicated the presence of a pre-Middle Horizon, EIP occupation ([37], 7; [40], 36). In addition to these four Huarpa settlements, there are other sites that include the hilltop of Churo Orqo found south of Vista Alegre. Another Huarpa settlement also existed across the deep canyon to the north of the core area of Huari and east of the contemporary town of Pacaycasa.

One additional settlement found in the immediate periphery of Huari is Huaqanmarka (Figures 2 and 3), located on a hilltop immediately to the west of the core area of Huari and Chupapata. Seen from its western side, the hilltop is similar to Cerro Baúl, an important Wari center in the Moquegua Valley of southern Peru [51, 74, 78]. The Huaqanmarka hilltop is surrounded by cliff formations of vertical drop that make its plateau relatively inaccessible. At present, there is only a single narrow pathway reaching the top from its northern 


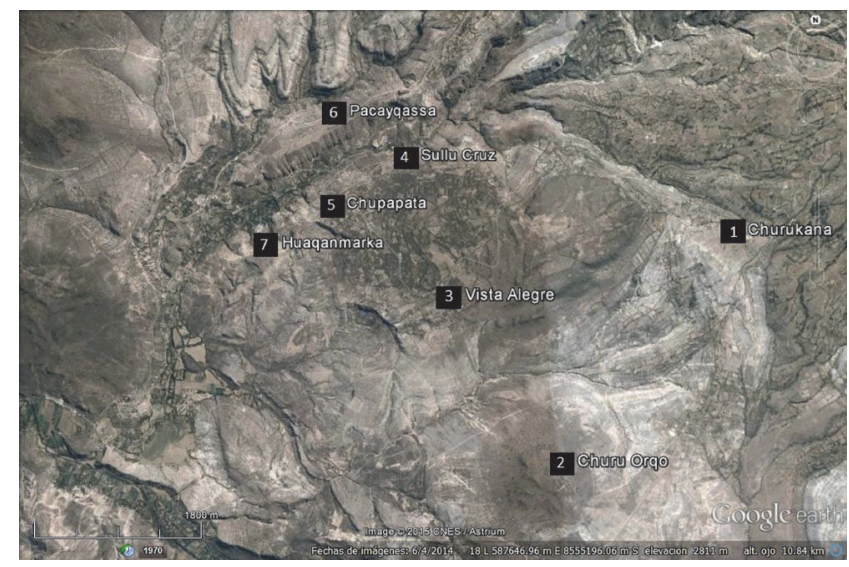

FIGURE 2: Map of location of Huaqanmarka in relationship with other Huarpa period villages mentioned in the text (1, Churukana; 2, Churu Orqo; 3, Vista Alegre; 4, Sullu Cruz; 5, Chupa Pata; 6, Pacayqasa; 7, Huaqanmarka).

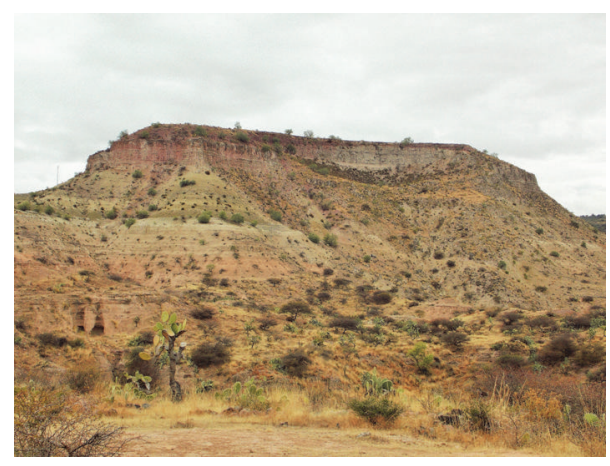

FIGURE 3: The hilltop of Huaqanmarka seeing from the western side.

side. Considering that the place is of difficult access and without a reliable source of water, it is possible that its occupation involved overcoming significant challenges; more importantly, there is the possibility that the hilltop may have been selected for the purposes of security. The hilltop is an excellent observation point, providing ample view of all the surroundings. Research at the hilltop was carried out in order to elucidate the history and nature of the ancient human occupation at the site; fieldwork consisted of a small-scale archaeological excavation carried out at the south end of the hilltop.

Information gathered from the first archaeological excavation at Huaqanmarka [53] indicates that prior to the Middle Horizon a sizable population existed at this location. The earliest occupation at the site is represented by a single relatively large-sized and rectangular-shaped structure, with walls constructed of chunks of clay and stone, mortared with mud, and established directly over a sterile formation (Figure 4). Later constructions were established immediately over the older building, thus demolishing most of the structure and obscuring its cultural associations.

Among the various archaeological remains present, ceramic sherds are the most recurrent artifacts. Furthermore, ceramics are very useful for the purposes of establishing

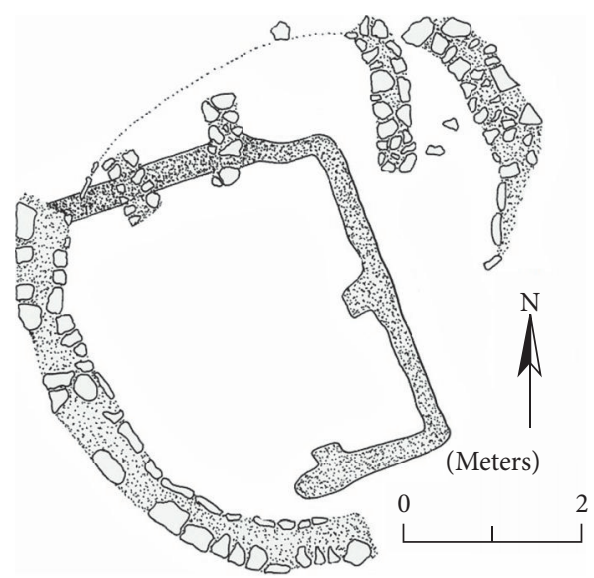

FIGURE 4: Earliest wall structure uncovered at Huaqanmarka.

the relative chronology of human occupation at the hilltop, particularly considering that no absolute dates exist yet. Sherds uncovered in association with the earliest structure consist of pieces that exhibit rough, uneven surfaces with poorly prepared grey paste, where temper inclusions are visible. In addition, on both surfaces there is an abundant presence of mica particles. Some of the sherds also exhibit pressed circular designs (Figure 5), which are typical of late Early Horizon ceramics of the region; however, most are of simple manufacture, likely indicative of the domestic orientation of the site. Indeed, several utilitarian vessel shapes have been determined, which include neck-less cooking pots and narrow neck jars. Most of these forms, in particular the jars, continued being made when new buildings were established at the hilltop.

Previously, the hilltop appears to have been visited only on occasion as the presence of some Early Horizon Wichqana ceramics indicates. However, Wichqana ceramics are rare and suggest that no permanent settlement existed then. Isbell $([28], 190)$ asserts that at Churukana there was an occupation associated with Wichqana-like ceramics. Because 


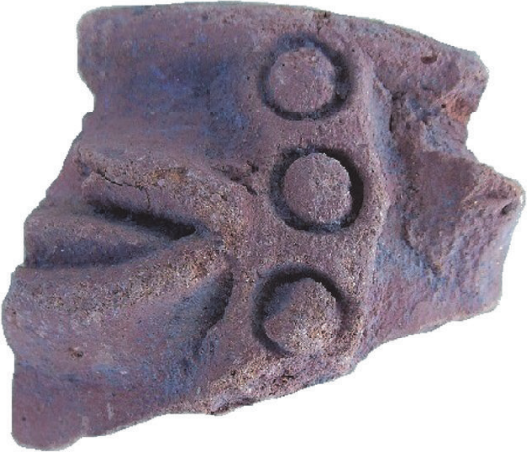

$(\mathrm{cm})$

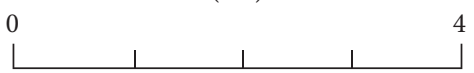

(a)

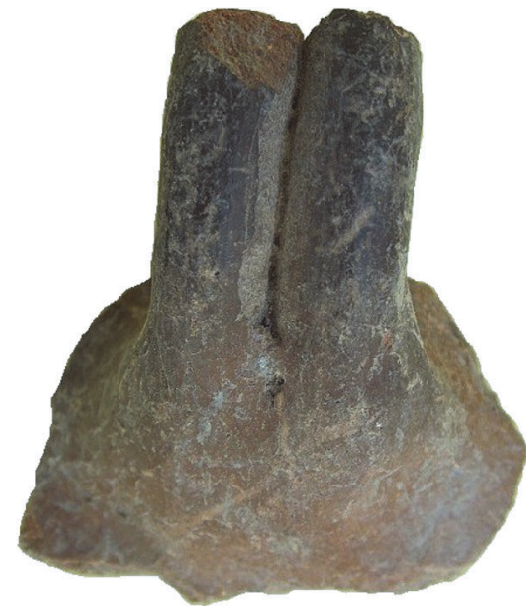

$(\mathrm{cm})$

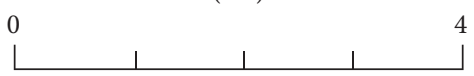

(b)

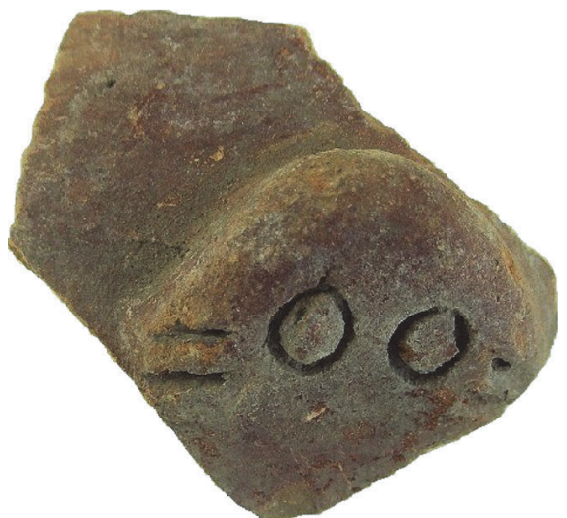

$(\mathrm{cm})$

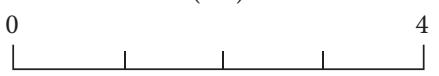

(c)

FIGURE 5: Ceramic sherds associated with the earliest structure of Huaqanmarka.

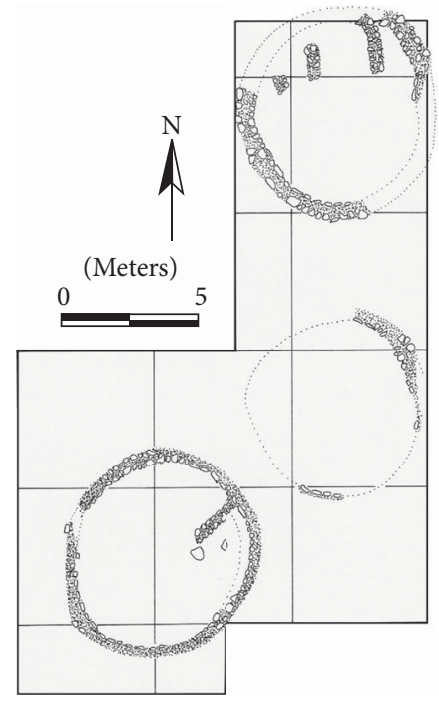

Figure 6: Circular stone-wall structures at Huaqanmarka.

the distance between Churukana and Huaqanmarka is short (see Figure 2), it is very likely that the early residents of the former visited the plateau of the latter. In addition to the rare occurrence of Wichqana style ceramics, Caja ceramics ([79], 75) that correspond to the late Early Horizon and the beginning of the EIP $([34], 136)$ are absent at the site.

Substantial human occupation at the hilltop occurred at the time circular stone-walled buildings were established (Figure 6), replacing the old structure. Unfortunately, contemporary farming activities have demolished most of the walls, in some instances even erasing them to their foundations. Therefore, site disturbance makes it difficult to assess the association of the artifacts with specific buildings because it is uncertain whether the depositions are original or the result of more recent activities. Despite these challenges, it was possible to determine three partially destroyed circular structures.

The most recurrent ceramic styles in association with the circular structures are those manufactured during the EIP $[34,35,37,80,81]$. This includes the distinctive thick-walled monochrome dark-red slip Kumun Senqa style (Figure 7) and the thick-walled with dense white unpolished surface named Huarpa Black-on-White style (Figure 8). Both of these ceramic styles correspond to large-sized, narrow neck, spherical body, and conical base vessels ([34], 136-137; [38], 84; [77]). Due to their large sizes and their conical bases, it is possible that these vessels functioned for the purpose of storing grains and beverages. In both styles, the surface of the vessels continues to be uneven, but partially polished, especially the exterior side, while the interior surface is smoothed only around the rim. Other small-sized vessels, particularly for the Huarpa Black-on-White, also occur. As noted, most of the vessel forms associated with the early structure persist in association with the circular structures and continue showing little sophistication. In addition to ceramics, there are other artifacts, particularly grinding stones and spindle whorls that as a whole indicate not only the presence of a substantial human occupation, but also the domestic character of the settlement.

Along with the above ceramic styles, there are other ceramic pieces also manufactured in the Huarpa Black-onWhite style, but that exhibit a much more sophisticated finishing. The vessels are thin-walled, with fine paste, and smooth surfaces that exhibit dark brown slip and white slip. These higher quality vessels often consist of tall drinking cups, deep bowls, and bottles. The most interesting aspect of the vessels is that these are the first of the Ayacucho Valley ceramics to depict foreign design elements, in this case late 


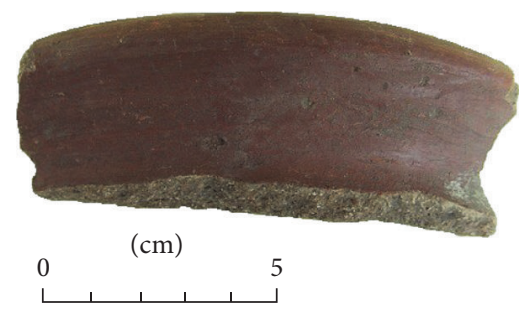

(a)

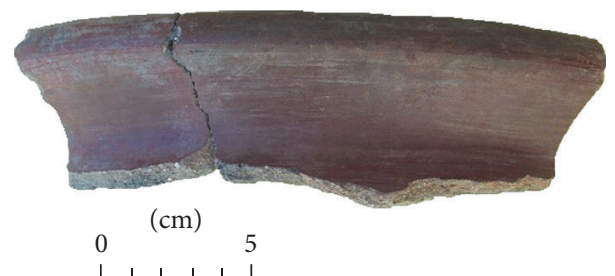

(b)

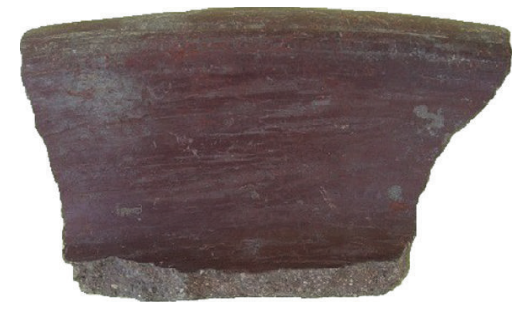

$(\mathrm{cm})$

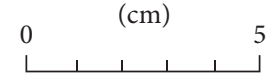

(c)

Figure 7: The Kumun Senqa ceramic style.

Nasca designs. The occurrence of late Nasca designs indicates that the interaction with the south coast must have been fluid ([37], 7; [82], 248).

The late Nasca motifs depicted in the Ayacucho Valley include one that appears to be the stylized versions of Nasca "bean pods" (Figures 9(a)) ([83], 164), in addition to what Proulx ([83], 186) identifies as the "flowering staff" (Figures 9(b), 9(c), and 9(d)), also recognized as the "black line spirals attached to bars" ([37]; [60], Plate 12; see also [84], Figure 93). Both of these decorative motifs appear on the south coast in Nasca phase 7 ceramics ([85], 95). As previously pointed out by Menzel ([37], 7), in addition to the designs and new colours, the shape of these vessels resembles late Nasca forms. Furthermore, these vessels exhibit obvious technological sophistication ([35], 116; [84], 125; [39], 38), sometimes as if were made by Nasca hands.

It is noteworthy that the ceramic styles that mark the end of the EIP and the beginning of the Middle Horizon period, such as Cruz Pata and Okros ([34], 138; [30], 24; [82], 248; [84], Figure 94; [37], 17; [38], 86), were not found at the hilltop. Such an absence strongly suggests that the hilltop was abandoned shortly after late Nasca designs began being depicted in the region and definitely before the above ceramic styles began being manufactured. However, on occasion the hilltop was visited during the Middle Horizon.

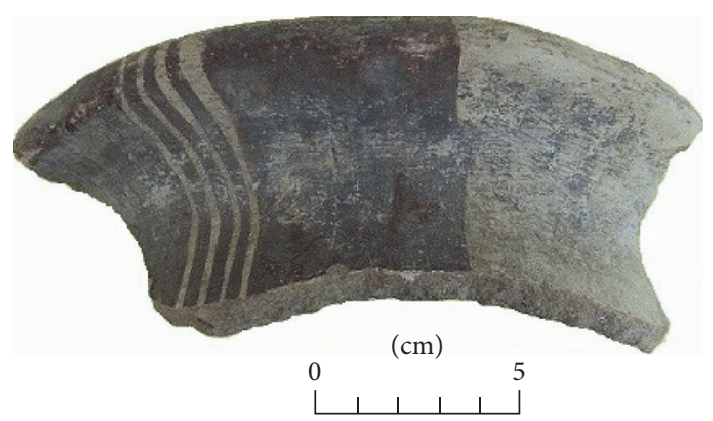

(a)

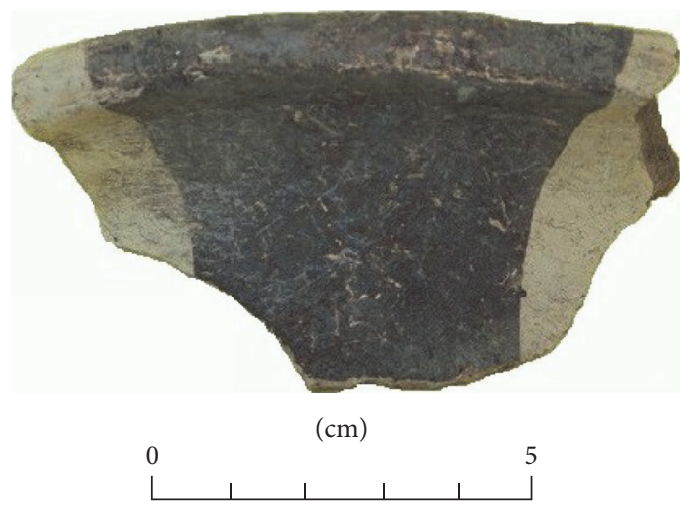

(b)

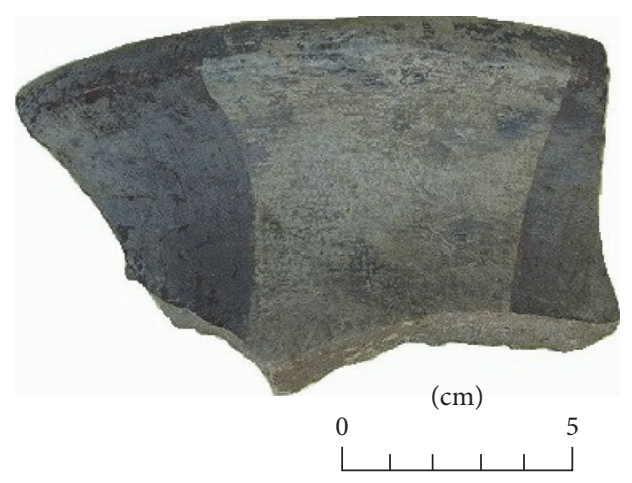

(c)

FIgURE 8: The Huarpa Black-on-White ceramic style.

To summarize, the ceramic evidence provides concrete information with regard to the events that took place immediately before the Middle Horizon in the area that eventually became the center of a powerful political organization, the Wari State. The archaeological evidence indicates that the hilltop was continuously occupied for several centuries and sustained a sizable, rural-oriented population. For reasons further discussed below, however, the settlement was left vacant shortly after the inhabitants of the Ayacucho Valley began depicting late Nasca designs, sometime late during the EIP. About the same time, other adjacent villages were also deserted, while a few others began to grow. It appears that, at this point, the small and rural villages that prevailed in the region for centuries were proving less viable than the emerging larger settlements. 


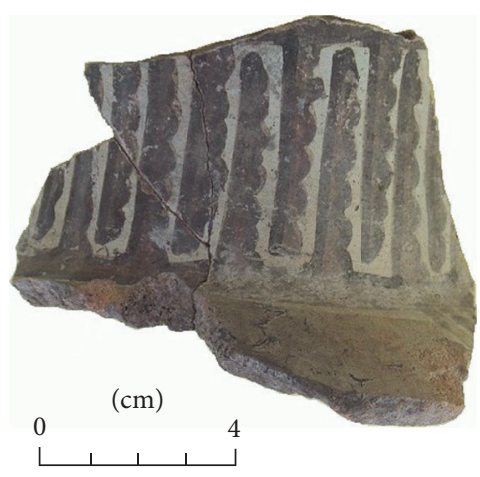

(a)

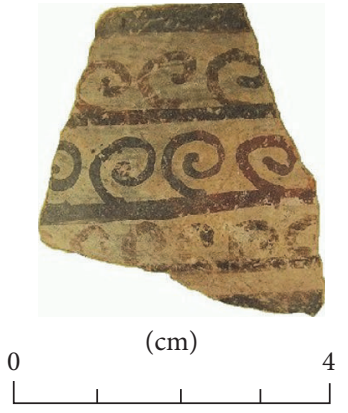

(b)

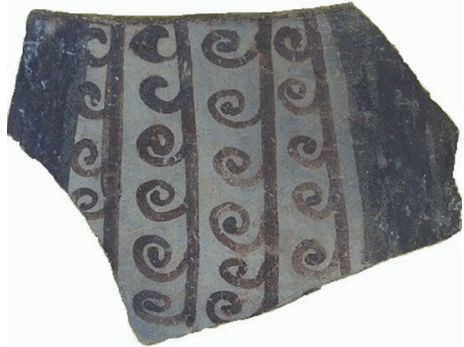

$(\mathrm{cm})$

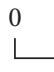

FIgURE 9: Late Huarpa ceramics depicting (a) late Nasca stylized bean pod motifs and (b, c, and d).

\section{Nucleation and the Growth of Huari}

Prior to the archaeological study carried out at Huaqanmarka, there were already some indications about the abandonment of other Huarpa villages. For instance, on the basis of surface ceramic collections, Menzel ([37], 5) was among the first to observe at Churukana an abundant occurrence of Early Intermediate period Huarpa ceramics; in contrast, Middle Horizon ceramics were rare. Thus, Menzel suggested that the settlement had been abandoned sometime at the end of the EIP. Test excavation conducted at the site largely corroborated the surface findings ([28],193). Lumbreras ([40], 37) asserts that Churukana was abandoned when its inhabitants migrated toward Huari.

A recent inspection of Churo Orqo, a second Huarpa site found on the hilltop immediately south of Huari (Figure 2), reveals the presence of some Huarpa sherds, but no Middle Horizon ceramics. This suggests that the site was also deserted around the same time. At Vista Alegre ([40], 146), a third Huarpa site found between the core area of Huari and Churu Orqo, there is an abundant surface occurrence of Huarpa ceramics ([28], 192; [82], 248; [37], 5-7; [29], 81), while Middle Horizon ceramics are less recurrent. Isbell [28] suggests that Vista Alegre was depopulated, perhaps about the same time as the other Huarpa villages mentioned here. Previously, MacNeish ([76], 224, Figures 8.11 and 8.12) had already showed for the entire Ayacucho Valley that the number of settlements between the Huarpa phase and the following Ocros Phase had decreased. As further discussed below, such a change likely was the outcome of population nucleation.

Parallel to such a drastic change in the local settlement patterns, some sites grew. Chupapata was one such settlement ([40], 37, 146; [28], 194; [77]). Sullu Cruz, another Huarpa phase settlement found only a short distance east from Chupapata (see Figure 2) and possibly also remained occupied. As a result of inflow of population, these two formerly small settlements appear to have joined and became a single but much larger center. Therefore, it is apparent that Huari arose over the foundation of these two Huarpa settlements ([33], 383 ; [29], 81). Thus, the history of development of Huari-in part-is similar to that of Uruk in southern Mesoptamia ([3], $11 ;$ [20], 64; [21]). Its eventual transformation into the largest settlement of the entire Central Andes seems to be linked to substantial emigration from the abandoned small rural Huarpa villages, such as Huaqanmarka, as further discussed below.

Archaeologists have long recognized the enormous size of Huari [25, 26, 29, 32, 33, 37]. How and under what circumstances Huari became the single largest settlement of the entire Central Andes have been little explored, with some notable exceptions [28, 30]. From the archaeological evidence presented in the previous section, it is evident that a number of Huarpa villages, such as Huaqanmarka, were abandoned some time at the end of the EIP ([40], 37); in contrast, other Huarpa settlements not only continued being occupied but also grew. This was the case of Chupapata and Sullu Cruz, settlements that appear to have joined when other neighbouring settlements were being deserted. Elsewhere in the valley, the number of settlements also decreased, suggesting that site desertion occurred valley wide. As some settlements were abandoned and others expanded, there can be little doubt that around this time population nucleation occurred in the Ayacucho Valley. What may have been the reason(s) for such a massive settlement abandonment and subsequent nucleation into few but much larger settlements? Unfortunately, archaeological evidence to discuss this critical issue for the case of the Ayacucho Valley is still fragmentary; consequently, one must infer what occurred in the region by combining bits of archaeological data coming from several places.

An important point that needs to be stressed here is that scholarly research argues that population aggregation in few but larger settlements ([1], 117-118) often reflects the need for defense due to threat ([86], 443-445; [19], 451, 472; [87], 398; [88], 299; [89], 168). The reasoning behind such a process is that larger settlements, perhaps better defended 
with human made barriers, are less likely to be attacked; in contrast, smaller settlements are more vulnerable to enemy offense [90].

Furthermore, Flannery and Marcus ([19], 374) point out that population nucleation in a specific area often results in the emergence of other nucleated settlements in adjacent areas with the aim of maintaining their autonomy and keeping potential aggressors at bay. Flannery and Marcus ([19], 459) further argue that in a conflictive situation the best alternative to maintain one's autonomy is to become big. This was the case, for example, in areas adjacent to the Oaxaca Valley following the establishment of Monte Albán ([16], 70). For the particular case of the Ayacucho Valley, it is asserted that at Conchopata, only $25 \mathrm{~km}$ south from Huari (see Figure 1), population clustering also occurred about the same time. Lumbreras ([40],37) argues that several smaller Huarpa settlements that existed around Conchopata [91] were abandoned as their inhabitants emigrated to Conchopata. Ñawinpukyo, an important EIP settlement found on a hilltop ([35], 105; [92, 93]) and only a short distance from Chonchopata, was of them ([40], 37). Isbell ([28], 195) acknowledges that, early in the development of Huari, Conchopata probably was its competitor. Future research may provide similar evidence for other sections (north) of the valley, but at present it is apparent that at least in two sections of the valley peoples aggregated about the same time in two larger and competing centers, leaving the rural areas partially deserted.

In addition, violent conflict often results in the establishment of defensive settlements, provided with human made barriers such as fortifications ([90], 513-515; [94], 121-122). Moreover, Allen and Arkush ([95], 7) assert that fortifications are not only one of the most obvious indicators of violent conflict, but also are archaeologically highly visible. Interestingly, not a single Huarpa period settlement can be securely identified as a fortification [42]. However, a number of Huarpa villages mentioned here, including Huaqanmarka, were established on defensive locations such as hilltops that perhaps were preferred for their military (defensibility and visibility) advantages. Nawinpukyo was also located on a hilltop ([35], 105). Thus, it is possible that some kind of conflict, perhaps between neighbouring villages, already existed in the region by the time contact with the south coast was established.

Furthermore, the clustering of larger populations in few centers often leaves extensive areas devoid of settlements ([18], 11803, [19], 455; [96], 15; [86], 443; [97], 342-343). For the area between Huari and Conchopata, besides perhaps the single early Middle Horizon site of Totorilla ([37], 6), there are no other known early Wari settlements. Moreover, Totorilla seems to represent only a brief occupation since it appears to have been eventually absorbed by either Conchopata or Huari, leaving the area vacant, perhaps as buffer zone.

Further indicating a violent situation, human body parts identified as trophies have been found in Huarpa phase contexts at Ñawimpukyo (see [98], 82-83). Skeletal trauma signaling face-to-face combat, arguably also took place at Conchopata during Huarpa times ([99], 103). Thus, there is evidence that already indicates the existence of violence in the region before the Middle Horizon. During the Middle
Horizon, as indicated in site nucleation, conflict in the region appears to have intensified as there is more evidence of violence in the form of skeletal trauma and iconography ([99], 99, 105-106; [100], 253). Available archaeological evidence, although limited, tends to support the idea that about the end of the EIP there was increased violence in the Ayacucho Valley.

The archaeological evidence coming from Huaqanmarka suggests that Huarpa villages were stable for most of their history. However, following interaction with the south coast the previously stable villages changed as indicated in settlement abandonment and the increased occurrence of evidence indicative of violent conflict. It appears that interaction with the south coast altered the course of cultural development in the Ayacucho Valley that seemingly also became increasingly violent. Here, it is vital to emphasize that interaction with neighbouring cultures can result in inequality ([19], 197). Indeed, as in the case discussed by Leach ([101], 219-222), it is possible that some Ayacucho Valley residents managed to elevate their prestige and perhaps wanted to cement their superiority. It is possible that such a desire resulted in competition that eventually had become violent. The south coast region has a long history of head hunting and human decapitation $[102,103]$ that probably resulted from raiding, practices that the Ayacucho Valley residents seem to have adopted.

It is opportune to mention that late Nasca settlements in the valleys of Palpa and Ingenio of the south coast of Peru decreased significantly in numbers and in size; it is suggested that these changes may be because a good number of the south coast population migrated elsewhere, perhaps to the Ayacucho Valley, in midst of a severe drought ([104], 27; [105], 245; [106], 231). Interestingly, Lumbreras ([30], 30) asserts that, at the time the ceramics of the Ayacucho Valley gained technological sophistication, the population had also increased in the region. Was this as a result of immigration from the south coast? Thus, it is tempting to argue that the changes observed in the Ayacucho Valley ceramics as well as the population increase perhaps were linked to south coast immigrants. By means of bioarchaeological and biochemical analysis, future researchers may be able to determine whether immigrants from the south coast had actually arrived to the Ayacucho Valley.

New archaeological evidence coming from north of the Ayacucho Valley suggests that interaction with the south coast also resulted in the introduction of the use of coca leaves to the Peruvian central highland region [107]. Indeed, about the time the inhabitants of the central highlands and the south coast had established interaction, there are depictions of coca chewers in Nasca ceramics, who interestingly also carry coca bags ([108], 55; [83], 174, Plate 37; [109], Figures. 063 and 064). Such depictions, as for the case of the Moche of the north coast ([110], 113; [111], 109; [112], 94), are suggestive of the practice of coca chewing on the south coast. Since there is not archaeological evidence for the use of coca leaves in the Ayacucho Valley prior to interaction with the south coast, the more likely scenario is that by late Nasca times coca leaves were already known on the south coast and subsequently were introduced to the Ayacucho Valley, 


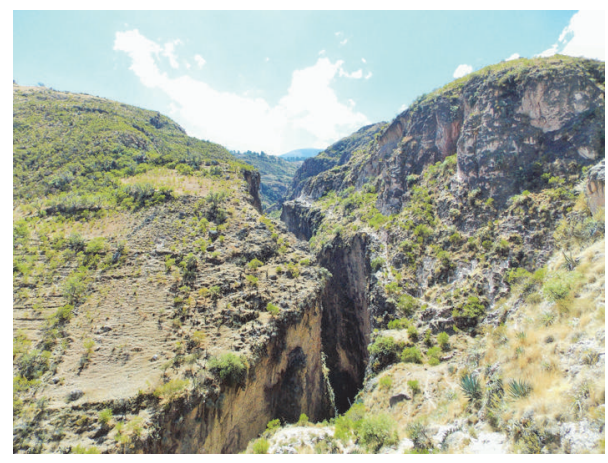

FIGURE 10: Deep canyon to the north of Huari that served as a natural barrier.

perhaps by Nasca immigrants. The recently found coca leaves are morphologically thinner (lanceolate) and small, features that match the main characteristics of $E$. novogranatense var. truxillense (coca Trujillo), species adapted to the Pacific coast ([113], 113; [110], 60).

In a conflictive context, competing leaders of settlements such as Huari and Conchopata probably were actively engaged in concentrating their followers into their respective centers that continued to grow ([59], 309). Such leaders likely understood that the only option to maintain autonomy was to become huge. However, in order to attract more followers, centers such as Huari had to be well defended to guarantee the safety of its residents. Interestingly, Lumbreras ([40], 38 ) asserts that Huari was a protected settlement, similar to Teotihuacan ([114]; [115], 192) and the city of Uruk ([116], 72; [19], 459). From its northern side Huari is impenetrable as it is protected by a deep canyon (Figure 10) that served as a natural barrier. The western side is also protected by deep cliffs. The eastern and southern sides more likely were secured by walls. Indeed, Lumbreras [40] states that a gate was located on the eastern side of the settlement. A similar gate likely also existed on the western side, by the Quebrada de Ocros. As in the case of Uruk ([15], 21, [3], 11; [19], 458-459), it is possible that rural Huarpa villages that felt exposed and vulnerable left their communities for the security provided by the walls of Huari. The manner in which Huari grew, which was without following a plan ([117], 57), may further explain that rural villages were abandoned within a short period of time. As new families arrived, it appears that new suburbs were established as rapidly as possible to accommodate newcomers. The challenging task at Huari is that most of its early structures remain buried deep by later buildings (Figure 11), making it difficult to comprehend its history of growth.

What has become apparent from this discussion is that the desertion of several small Huarpa villages coincides with the initial growth of Huari. By the time the Cruz Pata and Okros ceramic styles began to be manufactured in the Ayacucho Valley, Huari was already the single largest settlement in the entire Ayacucho Valley ([38], 87), perhaps challenged only by Conchopata. While Huari began to house a large number of residents and its size continued to increase ([31], 100, [32], 173, [28], 186), countless rural settlements were left vacant and the overall number of settlements in the valley decreased dramatically. Lumbreras ([40], 37-38) argues that this change represents the transition from rural to urban. As discussed here, what triggered such a dramatic transformation appears to be the competition between the residents of two sections of the Ayacucho Valley that ultimately culminated in the establishment of Huari and Conchopata. In this manner, the history of development of Huari appears to be similar to those of other urban centers such as Susa, Uruk, Nekhen, Teotihuacan, and Monte Albán. All these centers arose in the midst of conflict ([15], 21; [17], $129 ;[16], 123 ;[118], 260)$ that resulted in the "drawing together of the population into larger, more defensible political units" ([19], 472).

Population aggregation brought significant changes in the Ayacucho Valley. The peoples attracted by the defensive walls of centers such as Huari not only had to adjust to live in a much more crowded condition but also adapt to a much smaller space [119]. More importantly, the new structures established to house the new arrivals were markedly different from the ones they were familiar at their former settlements. The new buildings were rectangular or square and therefore different from the circular Huarpa structures.

\section{Conclusion}

This study presents information coming from a rural settlement established in the immediate periphery of the ancient city of Huari, but occupied prior to the emergence of Huari. As other adjacent settlements, the site was established on a hilltop that provided sweeping views of the immediate area in all directions. Ceramic evidence indicates that the hilltop was continuously occupied for several centuries but abandoned shortly after the Ayacucho Valley residents established interaction with the south coast. Available information, although limited, strongly indicates that about the time the hilltop was abandoned other neighbouring settlements were also deserted.

Parallel to the abandonment of the rural Huarpa villages, some settlements began to grow. Huari was one such settlement and there can be little doubt that it benefited from the desertion of the rural Huarpa villages. The cause of the unprecedented shift from a pattern of living based on small villages to one dominated by few but larger settlements appears to be violent conflict. The rapid clustering of a growing number of people into fewer but larger settlements (Huari, Conchopata) strongly suggests that violent conflict increased in the Ayacucho Valley. In this manner, Huari's growth appears to be comparable to that of cities such as Teotihuacan ([115], 191; [17], 129; [16], 129), Susa [22], Uruk ([15], 21, [3], 11; [19], 459) and Nekhen ([19], 404); in all cases people clustered in few, better protected settlements in the midst of increasing violence, thus giving rise to the urban centers.

Interaction with the south coast not only resulted in increasing conflict but also played a key role in the development of cultural complexity in the Ayacucho Valley. Archaeologists have long recognized the occurrence of late Nasca designs depicted in the Ayacucho Valley ceramics ([25], 128; 


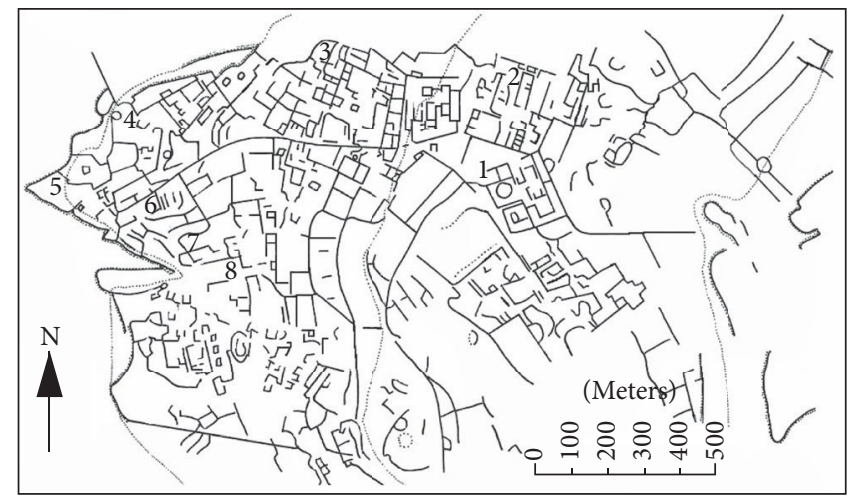

Figure 11: Partial map of the ancient urban center of Huari (1, Roblesmoqo; 2, Uchpaqoto; 3, Sullucruz; 4, Capillayoq; 5, Chupapata; 6, Monqaschayoq; 7, Moraduchaqoq; 8, Cheqo Wasi).

[26], 156; [116], 7); however, the mechanism of this interaction remains little understood. In addition to the late Nasca designs, the vessel shapes also resemble Nasca vessels. More importantly is that, following this interaction, the ceramics produced in the Ayacucho Valley became more sophisticated, colourful ([39], 38) and better finished. Simultaneously, the Nasca ceramics show clear loss of sophistication ${ }^{4}$. As noted, there are suggestions indicating that some south coast residents perhaps migrated toward the Ayacucho Valley. If demonstrated, it may explain the sophistication of the Ayacucho Valley ceramics. Thus, the south coast seems to have been actively involved in the local affairs of the Ayacucho Valley and this may be the reason why Nasca maintained a "privileged position" within the newly established Wari State ([37], 68). An additional important reason may have been the association of the south coast with coca leaves.

What is relevant for the purposes of this discussion is that, following the interaction with the south coast, society in the Ayacucho Valley was no longer the same. The new tendency became to live in larger settlements, instead of the small rural villages. Such a preference more likely was because the former were better protected than the dispersed rural villages that dominated the valley for centuries. Therefore, the case discussed here demonstrates that interaction resulted in significant change. It remains to be determined what were the consequences and conditions of taking up residence within the walls of centers such as Huari. It can be speculated that, in addition to loyalty, an important condition may have been to pay tribute to those who managed to establish the defensive facilities. The immigrants taking refuge in the better defended settlements evidently were willing to accept the conditions put on front of them in exchange for their security, likely including unequal access to resources, power, and prestige. Ultimately, as pointed out by Flannery and Marcus ([19], 472), accepting the conditions such as paying tribute was likely considered "the lesser of the two evils."

\section{Competing Interests}

There is no conflict of interests regarding the publication of this paper.

\section{Acknowledgments}

Research at Huaqanmarka was carried out with authorization from the Peruvian Ministerio de la Cultura (Resolución Directoral no. 289-DGPC-VMPCIC/MC) and financial assistance from the Scholarly Activity and Achievement Research Grant of MacEwan University (Canada). The authors extend their gratitude to Fernando Huaqueriso, Yoni Llimpe, Roberto Tello, Edwin Guerrero, and Eloy Espinoza for their participation in the field activities carried out at Huaqanmarka. Patricia J. Knobloch kindly assisted with the stylistic identification of the ceramic samples from Huaqanmarka. The authors' gratitude also goes to Katrina J. Bettcher and J. Scott Raymond for their comments and editorial assistance. Any shortcomings are only the authors.

\section{Endnotes}

1. Huari with $\mathbf{H}$ refers to the capital urban center while Wari with $\mathbf{W}$ refers to the state.

2. It has been suggested that at its climax Huari housed a large population, estimates ranging around 10,000 and 70,000 inhabitants (see [28], 186).

3. Until the site of Huari was rediscovered by J. C. Tello, archaeologists assumed that the Tiahuanacoid art spread from the site of Tiwanaku; later research would prove that Huari was the heart of dispersal of the so-called Tiahuanacoid art, now Wari art style.

4. The south coast was one of the first regions conquered by the Wari State [37].

\section{References}

[1] M. S. Chesson and N. Goodale, "Population aggregation, residential storage and socioeconomic inequality at Early Bronze Age Numayra, Jordan," Journal of Anthropological Archaeology, vol. 35, no. 1, pp. 117-134, 2014.

[2] G. L. Cowgill, "Origins and development of urbanism: archaeological perspectives," Annual Review of Anthropology, vol. 33, pp. 525-549, 2004. 
[3] R. M. Adams, "Ancient mesopotamian urbanism and blurred disciplinary boundaries," Annual Review of Anthropology, vol. 41, pp. 1-20, 2012.

[4] M. L. Smith, "The archaeology of urban landscapes," Annual Review of Anthropology, vol. 43, pp. 307-323, 2014.

[5] P. Geddes, Cities in Evolution, Williams and Norgate, London, UK, 1949.

[6] M. Batty, The Emergence of Cities: Complexity and Urban Dynamics, vol. 64 of Centre for Advanced Spatial Analysis Working Paper Series, University College of London, London, UK, 2003.

[7] D. S. Dendrinos and H. Mullally, Urban Evolution: Studies in the Mathematical Ecology of Cities, Donnan, Christopher B, Oxford University Press, Oxford, UK, 1985.

[8] C. Goucher, C. LeGuin, and L. Walton, In the Balance: Themes in World History, McGraw-Hill, Boston, Mass, USA, 1998.

[9] K. V. Flannery, "The cultural evolution of civilizations," Annual Review of Ecology and Systematics, vol. 3, no. 1, pp. 399-426, 1972.

[10] C. M. Sinopoli, “The archaeology of empires," Annual Review of Anthropology, vol. 23, no. 1, pp. 159-180, 1994.

[11] K. Makowski, "Andean urbanism," in Handbook of South American Archaeology, H. Silverman and W. H. Isbell, Eds., pp. 633657, Springer, New York, NY, USA, 2008.

[12] H. Isbell William, "Wari and Tiwanaku: international identities in the Central Andean Middle Horizon," in Handbook of South American Archaeology, H. Silverman and W. H. Isbell, Eds., pp. 731-759, Springer, New York, NY, USA, 2008.

[13] C. Stanish, "The origin of state societies in South America," Annual Review of Anthropology, vol. 30, pp. 41-64, 2001.

[14] R. M. A. Adams and E. W. Richard, The Evolution of Urban Society: Early Mesopotamia and Prehispanic Mexico, Aldine Publishing Company, Chicago, Ill, USA, 1966.

[15] R. Adams, "Spatial and temporal patterns of early urbanization," in The Uruk Countryside: the Natural Setting of Urban Societies, R. Adams and H. J. Nissen, Eds., pp. 9-33, University of Chicago Press, Chicago, Ill, USA, 1972.

[16] R. E. Blanton, S. A. Kowalewski, G. M. Feinman, and L. M. Finsten, Ancient Mesoamerica: A Comparison of Change in Three Regions, Cambridge University Press, Cambridge, UK, 2nd edition, 1993.

[17] G. L. Cowgill, "State and society at Teotihuacan, Mexico," Annual Review of Anthropology, vol. 26, pp. 129-161, 1997.

[18] K. V. Flannery and J. Marcus, "The origin of war: new ${ }^{14} \mathrm{C}$ dates from ancient Mexico," Proceedings of the National Academy of Sciences of the United States of America, vol. 100, no. 20, pp. 11801-11805, 2003.

[19] K. V. Flannery and J. Marcus, The Creation of Inequality: How Our Prehistoric Ancestors Set the Stage for Monarchy, Slavery, and Empire, Harvard University Press, Cambridge, UK, 2012.

[20] J. R. Mcintosh, Ancient Mesopotamia: New Perspectives, ABCCLIO Corporate, Santa Barbara, Calif, USA, 2005.

[21] H. J. Nissen, "Uruk: key site of the period and key site of the problem," in Artifacts of Complexity: Tracking the Uruk in the Near East, J. N. Postgate, Ed., pp. 1-17, British School of Archaeology in Iraq, London, UK, 2002.

[22] H. T. Wright and G. A. Johnson, "Population, exchange, and early state formation in southwestern Iran," American Anthropologist, vol. 77, no. 2, pp. 267-289, 1975.
[23] H. T. Wright, "Toward an explanation of the origin of the state," in Explanation of Prehistoric Change, J. Hill, Ed., pp. 215-230, University of New Mexico Press, Albuquerque, NM, USA, 1977.

[24] V. G. Childe, Man Makes Himself, The New American Library of World Literature, INC, London, UK, 1951.

[25] J. H. Rowe, D. Collier, and G. R. Willey, "Reconnaissance notes on the site of Huari, near Ayacucho, Peru," American Antiquity, vol. 16, no. 2, pp. 120-137, 1950.

[26] L. G. Lumbreras, "La cultura Wari," Etnología y Arqueología, vol. 1, pp. 130-227, 1960, Instituto de Etnología y Arqueología, Universidad Nacional Mayor de San Marcos, Lima.

[27] L. G. Lumbreras, "Introduction," in Wari, Lords of the Ancient Andes, L. E. Oscar, Ed., pp. 1-3, The Cleveland Museum of Art and Thames and Hudson, New York, NY, USA, 2012.

[28] W. H. Isbell, "Reconstructing Huari: a cultural chronology for the capital city," in Emergence and Change in Early Urban Societies, L. Manzanilla, Ed., pp. 181-227, Plenum Press, New York, NY, USA, 1997.

[29] J. Schreiber Katharina, “The Wari Empire of Middle Horizon Peru: the epistemological challenge of documenting an empire without documentary evidence," in Empires, S. E. Alcock, T. N. D'Altroy, K. D. Morrison, and C. M. Sinopoli, Eds., pp. 70-92, Cambridge University Press, Cambridge, Mass, USA, 2001.

[30] L. G. Lumbreras, "El Imperio Wari," in Historiad el Perú, vol. 2, pp. 9-91, Editorial Juan Mejia Baca, Lima, Peru, 1980.

[31] H. Isbell William, "Huari urban prehistory," in Current Archaeological Projects in the Central Andes, A. Kendall, Ed., vol. 210 of British Archaeological Reports International Series, pp. 95-135, Oxford University Press, Oxford, UK, 1984.

[32] W. H. Isbell, "City and state in Middle Horizon Peru," in Peruvian Prehistory, R. Keatinge, Ed., pp. 164-189, Cambridge University Press, Cambridge, UK, 1988.

[33] W. H. Isbell and K. J. Schreiber, "Was Huari a state?" American Antiquity, vol. 43, no. 3, pp. 372-389, 1978.

[34] L. G. Lumbreras, The Peoples and Cultures of Ancient Peru, Smithsonian Institution Press, Washington, DC, USA, 1974.

[35] L. G. Lumbreras, Las Fundaciones de Huamanga: Hacia una Prehistoria de Ayacucho, Club de Huamanga, Lima, Peru, 1975.

[36] J. H. Rowe, "Urban settlements in Ancient Peru," Nawpa Pacha, vol. 1, pp. 1-28, 1963.

[37] D. Menzel, "Style and time in the Middle Horizon," Nawpa Pacha, vol. 2, no. 1, pp. 1-105, 1964.

[38] K. J. Schreiber, Wari Imperialism in Middle Horizon Peru, vol. 87 of Museum of Anthropology, Anthropological Papers, University of Michigan, Ann Arbor, Mich, USA, 1992.

[39] K. J. Schreiber, “The rise of an Andean Empire," in Wari, Lords of the Ancient Andes, L. E. Oscar, Ed., pp. 31-45, The Cleveland Museum of Art and Thames and Hudson, New York, NY, USA, 2012.

[40] L. G. Lumbreras, Plan de Manejo Del Complejo Arqueológico Wari, Ayacucho, Gobierno Regional de Ayacucho, Plan Copesco Nacional, Ayacucho, Peru, 2010.

[41] W. H. Isbell and M. Young-Sánchez, "Wari's Andean legacy," in Wari, Lords of the Ancient Andes, L. E. Oscar, Ed., pp. 251-267, The Cleveland Museum of Art and Thames and Hudson, New York, NY, USA, 2012.

[42] W. H. Isbell, "Conchopata, ideological innovator in Middle Horizon 1A," in Ñawpa Pacha, pp. 22-23; 91-134, 1987.

[43] W. H. Isbell and A. G. Cook, "Ideological origins of an Andean conquest state," Archaeology, vol. 40, no. 4, pp. 27-33, 1987. 
[44] W. H. Isbell and P. J. Knobloch, "SAIS-the origin, development, and dating of Tiahuanaco-Huari iconography," in Tiwanaku: Papers from the 2005 Mayer Center Symposium a the Denver Art Museum, M. Young-Sánchez, Ed., pp. 165-210, Denver Art Museum, Boulder, Colo, USA, 2009.

[45] G. Cook Anita, "The coming of the staff deity," in Wari, Lords of the Ancient Andes, L. E. Oscar, Ed., pp. 103-121, The Cleveland Museum of Art and Thames and Hudson, New York, NY, USA, 2012.

[46] J. H. Rowe, "Archaeological explorations in southern peru, 19541955," American Antiquity, vol. 22, no. 2, pp. 135-151, 1956.

[47] K. J. Schreiber, "From state to empire: the expansion of the Wari State outside the Ayacucho Basin," in The Origins and Development of the Andean State, J. Haas, S. Pozorski, and T. Pozorski, Eds., pp. 91-96, Cambridge University Press, Cambridge, UK, 1987.

[48] G. F. McEwan, "Investigations at the Pikillacta Site: a provincial Huari center in the Valley of Cuzco," in Huari Administrative Structure: Prehistoric Monumental Architecture and State Government, W. H. Isbell and G. F. McEwan, Eds., pp. 93-119, Dumbarton Oaks, Washington, DC, USA, 1991.

[49] G. F. McEwan, "Archaeological investigations at pikillacta, a wari site in peru," Journal of Field Archaeology, vol. 23, no. 2, pp. 169-186, 1996.

[50] G. F. McEwan, Pikillacta: The Wari Empire in Cusco, University of Iowa Press, Iowa City, Iowa, USA, 2005.

[51] G. F. McEwan and P. R. Williams, "The Wari built environment: landscape and architecture of empire," in Wari, Lords of the Ancient Andes, L. E. Oscar, Ed., pp. 65-81, The Cleveland Museum of Art and Thames and Hudson, New York, NY, USA, 2012.

[52] D. Nash and R. P. Williams, "Wari political organization on the southern periphery," in Andean Civilization: A Tribute to Michael E. Moseley, J. Marcus and P. R. Williams, Eds., pp. 257276, Cotsen Institute of Archaeology Press, UCLA, Los Angeles, Calif, USA, 2009.

[53] L. M. Valdez and J. E. Valdez, "Highland and coastal cultural interaction: new evidence from the ancient city of Huari, Ayacucho, Peru," in Proceedings of the 46th Annual Chacmool Archaeology Conference, Trading Spaces: The Archaeology of Interaction, Migration and Exchange, University of Calgary, November 2013.

[54] P. Cieza de León, [1553] La Crónica del Perú, Ediciones PEISA Biblioteca Peruana, Lima, Peru, 1973.

[55] W. H. Isbell and G. F. McEwan, "A history of Huari studies and introduction to current interpretations," in Huari Administrative Structure: Prehistoric Monumental Architecture and State Government, W. H. Isbell and G. F. McEwan, Eds., pp. 1-17, Washington, DC, USA, Dumbarton Oaks, 1991.

[56] A. L. Kroeber, Peruvian Archaeology in 1942, Viking Fund Publications in Anthropology 4, Wenner-Green Foundation for Anthropological Research, New York, NY, USA, 1944.

[57] G. R. Willey, "A functional analysis of 'Horizon Styles' in Peruvian archaeology," in A Reappraisal of Peruvian Archaeology, W. C. Bennett, Ed., vol. 13, no. 4, part 2 of Memoirs of the Society for American Archaeology, pp. 8-15, Society for American Archaeology, 1948.

[58] W. C. Bennett and J. B. Bird, Andean Culture History, The American Museum of Natural History, New York, NY, USA, 1949.

[59] W. H. Isbell, "Conclusion: Huari administration and the orthogonal cellular architecture horizon," in Huari Administrative
Structure: Prehistoric Monumental Architecture and State Government, W. H. Isbell and G. F. McEwan, Eds., pp. 293-315, Dumbarton Oaks, Washington, DC, USA, 1991.

[60] W. C. Bennett, Excavations at Wari, Ayacucho, Peru, Yale University Publications in Anthropology 49, Yale University Press, 1953.

[61] M. Benavides, "Cheqo Wasi, Wari," in Huari Administrative Structure: Prehistoric Monumental Architecture and State Government, W. H. Isbell and G. F. McEwan, Eds., pp. 55-70, Dumbarton Oaks, Washington, DC, USA, 1991.

[62] E. Bragayrac, "Archaeological excavations in the Vegachayoq Sector of Wari," in Huari Administrative Structure: Prehistoric Monumental Architecture and State Government, W. H. Isbell and G. F. McEwan, Eds., Chesson, Meredith S. and Nathan Goodale, pp. 71-80, Dumbarton Oaks, Washington, DC, USA, 1991.

[63] W. H. Isbell, C. Brewster-Wray, and A. Lynda, "Architecture and spatial organization at Huari," in Huari Administrative Structure: Prehistoric Monumental Architecture and State Government, W. H. Isbell and G. F. McEwan, Eds., pp. 19-54, Dumbarton Oaks, Washington, DC, USA, 1991.

[64] M. Benavides, Caracter del Estado Wari, Universidad de Huamanga, Ayacucho, Peru, 1984.

[65] J. A. Ochatoma and M. Cabrera, "Descubrimientos del área ceremonial de Conchopata, Huari," in XII Congreso Peruano del Hombre y la Cultura Andina Luis G. Lumbreras, vol. 1, pp. 212-245, Universidad Nacional de San Cristóbal de Huamanga, Ayacucho, Peru, 1999.

[66] I. Pérez Calderón, "Investigaciones en la periferia del complejo Huari," in XII Congreso Peruano del Hombre y la Cultura Andina Luis G. Lumbreras, vol. 2, pp. 246-270, Universidad Nacional de San Cristóbal de Huamanga, Ayacucho, Peru, 2001.

[67] L. M. Valdez, "Variabilidad y función de la cerámica del sitio Wari de Marayniyoq, Ayacucho, Perú," Arqueología y Sociedad, vol. 15, pp. 61-92, 2004.

[68] L. M. Valdez, "Maize beer production in Middle Horizon Peru," Journal of Anthropological Research, vol. 62, no. 1, pp. 53-80, 2006.

[69] L. M. Valdez, K. J. Bettcher, and J. Ernesto Valdez, "Una cámara funeraria en Seqllas, Valle de Ayacucho," Boletín del Museo de Arqueología y Antropología, vol. 3, no. 7, pp. 2-7, 2000.

[70] L. M. Valdez and J. Ernesto Valdez, "Inkapyarqan: un canal en las punas de Ayacucho," Boletín del Museo de Arqueología y Antropología, vol. 1, no. 6, pp. 4-9, 1998.

[71] P. Kaulicke and W. H. Isbel, Eds., Huari y Tiwanaku: Modelos vs. Evidencias. Departamento de Humanidades, Pontificia Universidad Católica del Perú, Lima, Peru, 2001.

[72] M. Glowacki, “The Huaro archaeological site complex: rethinking the Huari occupation of Cuzco," in Andean Archaeology I: Variation and Sociopolitical Organization, W. H. Isbell and H. Silverman, Eds., pp. 267-284, Kluwer Academic/Plenum, New York, NY, USA, 2002.

[73] M. Glowacki, "Shattered ceramics and offerings," in Wari, Lords of the Ancient Andes, L. E. Oscar, Ed., pp. 145-157, The Cleveland Museum of Art and Thames and Hudson, New York, NY, USA, 2012.

[74] P. R. Williams, "Cerro Baúl: a Wari center in the Tiwanaku frontier," Latin American Antiquity, vol. 12, no. 1, pp. 67-83, 2001.

[75] M. Benavides, Sitios Arqueológicos de Ayacucho, Universidad de Huamanga, Ayacucho, Peru, 1976. 
[76] S. MacNeish Richard, "Synthesis and conclusions," in Prehistory of the Ayacucho Basin, Peru, Vol II: Excavations and Chronology, R. S. MacNeish, Ed., pp. 199-257, R. S. Peabody Foundation for Archaeology. The University of Michigan Press, Ann Arbor, Mich, USA, 1981.

[77] P. J. Knobloch, An Early Intermediate Period Deposit of Huarpa Style Ceramics from the Site of Huari, Arkeo Ayacucho Peru, Department of Ayacucho, Peru, 2013.

[78] P. R. Williams and D. Nash, "Imperial interactions in the Andes: Wari and Tiwanaku at Cerro Baúl," in Andean Archaeology I: Variation and Sociopolitical Organization, W. H. Isbell and H. Silverman, Eds., pp. 243-265, Kluwer Academic/Plenum, New York, NY, USA, 2002.

[79] L. G. Lumbreras, "Esquema arqueológico de la sierra central del Peru," Revista del Museo Nacional, vol. 28, pp. 64-117, 1959.

[80] L. M. Valdez, "The early intermediate period beyond the Ayacucho Valley, Peru," in Debating Complexity, D. Meyer, P. Dawson, and D. Hannan, Eds., pp. 600-606, The Archaeological Association of the University of Calgary, Calgary, Canada, 1996.

[81] L. M. Valdez, "Ecology and ceramic production in an Andean community: a reconsideration of the evidence," Journal of Anthropological Research, vol. 53, no. 1, pp. 65-85, 1997.

[82] P. J. Knobloch, "Stylistic date of ceramics from the Huari centers," in Huari Administrative Structure: Prehistoric Monumental Architecture and State Government, W. H. Isbell and G. F. McEwan, Eds., pp. 247-258, Dumbarton Oaks, Washington, DC, USA, 1991.

[83] D. A. Proulx, A Source Book of Nasca Iconography, University of Iowa Press, Iowa City, Iowa, USA, 2006.

[84] J. Knobloch Patricia, "Archives in clay the styles and stories of Wari ceramic artists," in Wari, Lords of the Ancient Andes, L. E. Oscar, Ed., pp. 122-142, The Cleveland Museum of Art and Thames and Hudson, New York, NY, USA, 2012.

[85] D. A. Proulx, "Stylistic variation in proliferous Nasca pottery," Andean Past, vol. 4, pp. 91-107, 1994.

[86] S. A. LeBlanc, "Warfare and the development of social complexity," in The Archaeology of Warfare: Prehistories of Raiding and Conquest, E. N. Arkush and M. W. Allen, Eds., pp. 437-468, University Press of Florida, Gainesville, Fla, USA, 2006.

[87] R. B. Haymes, "The settlement patterns of the Yanomamo population block: a behavioral ecological interpretation," in Adaptive Responses of Native Amazonians, R. B. Haymes and W. T. Vickers, Eds., pp. 393-427, Academic Press, New York, NY, USA, 1983.

[88] M. Elliott, "Evaluating evidence for warfare and environmental stress in settlement pattern data from the Malpaso valley, Zacatecas, Mexico," Journal of Anthropological Archaeology, vol. 24, no. 4, pp. 297-315, 2005.

[89] K. J. Schreiber, "Regional approaches to the study of prehistoric empires: examples from Ayacucho and Nasca, Peru," in Settlement Pattern Studies in the Americas: Fifty Years Since Virú, B. R. Billman and G. M. Feinman, Eds., pp. 160-171, Smithsonian Institution Press, Washington, DC, USA, 1999.

[90] P. Roscoe, "Settlement fortification in village and "Tribal" society: evidence from contact-era New Guinea," Journal of Anthropological Archaeology, vol. 27, no. 4, pp. 507-519, 2008.

[91] I. Pérez Calderón, "Asentamientos periféricos del centro urbano de Conchopata, Ayacucho," Arqueología y Sociedad, vol. 25, pp. 143-168, 2012.

[92] J. B. Leoni, "Ritual and society in early intermediate period ayacucho: a view from Nawinpukyo," in Andean Archaeology
III: North and South, W. H. Isbell and H. Silverman, Eds., pp. 279-306, Springer, New York, NY, USA, 2006.

[93] J. B. Leoni, "Early intermediate period and middle horizon funerary practices in Ayacucho: a view from the site of Ñawinpukyo," Nawpa Pacha, vol. 30, no. 1, pp. 65-90, 2010.

[94] B. G. Trigger, "Monumental architecture: a thermodynamic explanation of symbolic behaviour," World Archaeology, vol. 22, no. 2, pp. 119-132, 1990.

[95] M. W. Allen and E. N. Arkush, "Introduction: archaeology and the study of war," in The Archaeology of Warfare: Prehistoric Raiding and Conquest, E. N. Arkush and M. W. Allen, Eds., pp. 1-19, University of Florida Press, Gainesville, Fla, USA, 2006.

[96] E. Arkush and C. Stanish, "Interpreting conflict in the ancient Andes: implications for the archaeology of warfare," Current Anthropology, vol. 46, no. 1, pp. 3-28, 2005.

[97] E. M. Redmond and C. S. Spencer, "From raiding to conquest: warfare strategies and early state development in Oaxaca, Mexico," in The Archaeology of Warfare: Prehistories of Raiding and Conquest, E. N. Arkush and M. W. Allen, Eds., pp. 336-393, University Press of Florida, Gainesville, Fla, USA, 2006.

[98] B. C. Finucane, "Trophy heads from Nawinpukio, Perú: physical and chemical analysis of Huarpa-era modified human remains," American Journal of Physical Anthropology, vol. 135, no. 1, pp. 75-84, 2008.

[99] T. A. Tung, Violence, Ritual and the Wari Empire: A Social Bioarchaeology of Imperialism in the Ancient Andes, University of Florida Press, Gainesville, Fla, USA, 2012.

[100] T. A. Tung and K. J. Knudson, "Identifying locals, migrants, and captives in the Wari Heartland: a bioarchaeological and biogeochemical study of human remains from Conchopata, Peru," Journal of Anthropological Archaeology, vol. 30, no. 3, pp. 247-261, 2011.

[101] E. R. Leach, Political Systems of Highland Burma: A Study of Kachin Social Structure, vol. 44 of London School of Economics, Monographs in Social Anthropology, The Athlone Press, London, UK, 1990.

[102] D. A. Proulx, "Ritual uses of trophy heads in ancient Nasca society," in Ritual Sacrifice in Ancient Peru, E. Benson and A. Cook, Eds., pp. 119-136, University of Texas Press, Austin, Tex, USA, 2001.

[103] L. M. Valdez, "Walled settlements, buffer zones, and human decapitation in the Acari Valley, Peru," Journal of Anthropological Research, vol. 65, no. 3, pp. 389-416, 2009.

[104] B. Eitel and B. Mätchel, "Man and environment in the eastern Atacama Desert (southern Peru): holocene climate changes and their impact on pre-Columbian cultures," in New Technologies for Archaeology: Multidisciplinary Investigations in Palpa and Nasca, Peru, M. Reindel and G. A. Wagner, Eds., pp. 17-37, Spinger, Berlin, Germany, 2009.

[105] C. A. Conlee, "Nasca culture integration and complexity: a perspective from the site of La Tiza," Journal of Anthropological Archaeology, vol. 35, no. 1, pp. 234-247, 2014.

[106] V. Sossna, Impacts of Climate Variability on Prehispanic Settlement Behavior in South Peru: the northern Rio Grande drainage between 15000 BCE and 1532 CE [Ph.D. dissertation der Mathematisch], Naturwissenschaftlichen Fakultät der Christian-Albrechts-Universität zu Kiel vorgelegt von, Bonn, Germany, 2014.

[107] L. M. Valdez and J. Taboada, "The use of coca leaves in the Peruvian central highlands before the Inka," in Proceedings of 
the 42nd Annual Midwest Conference on Andean and Amazonian Archaeology and Ethnohistory, University of Wisconsin Milwaukee, Milwaukee, Wis, USA, March 2014.

[108] H. Silverman and D. A. Proulx, The Nasca, Blackwell, Massachusetts, Mass, USA, 2002.

[109] I. Shimada, T. Baba, K. Shinoda, and M. Ono, Eds., Nasca, Wonder of the World. Messages Etched on the Desert Floor, Broadcasting System and National Science Museum, Tokyo, Japan, 2006.

[110] M. A. Towle, The Ethnobotany of Pre-Columbian Peru, Aldine Transaction, London, UK, 2007.

[111] E. P. Benson, The Worlds of the Moche on the North Coast of Peru, University of Texas Press, Austin, Tex, USA, 2012.

[112] C. B. Donnan, Moche Art and Iconography, vol. 33 of Moche Art and Iconography. Latin American Studies Publication, University of California, Los Angeles, Calif, USA, 1976.

[113] T. Plowman, "Botanical perspectives on coca," Journal of Psychedelic Drugs, vol. 11, no. 1-2, pp. 103-117, 1979.

[114] C. Millon, "Painting, writing, and polity in Teotihuacan, Mexico," American Antiquity, vol. 38, no. 3, pp. 294-314, 1973.

[115] R. E. W. Adams, Prehistoric Mesoamerica, Little, Brown and Company, Boston, Mass, USA, 1977.

[116] S. Pallock, Ancient Mesopotamia, Cambridge University Press, Cambridge, UK, 1999.

[117] L. G. Lumbreras, Una Nueva Visión Del Antiguo Perú, Municipalidad de Lima, Lima, Peru, 1986.

[118] J. Marcus, "The archaeological evidence for social evolution," Annual Review of Anthropology, vol. 37, pp. 251-266, 2008.

[119] K. V. Flannery, "The origins of the village revisited: from nuclear to extended households," American Antiquity, vol. 67, no. 3, pp. 417-433, 2002. 


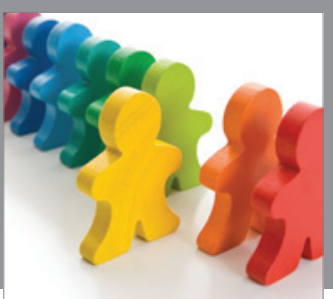

Autism

Research and Treatment
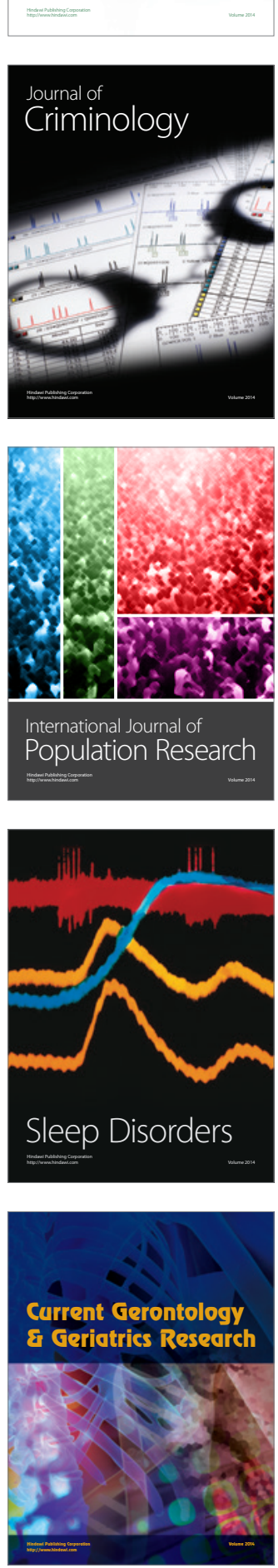

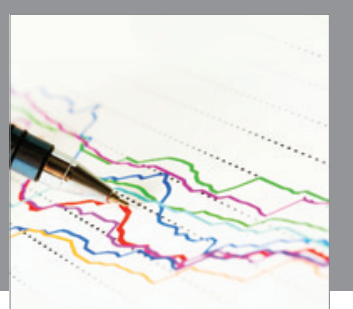

Economics

Research International
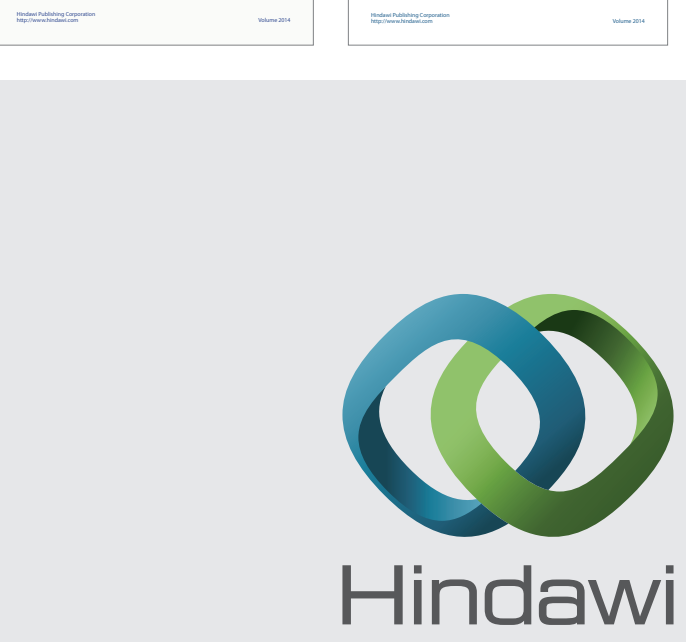

Submit your manuscripts at

https://www.hindawi.com
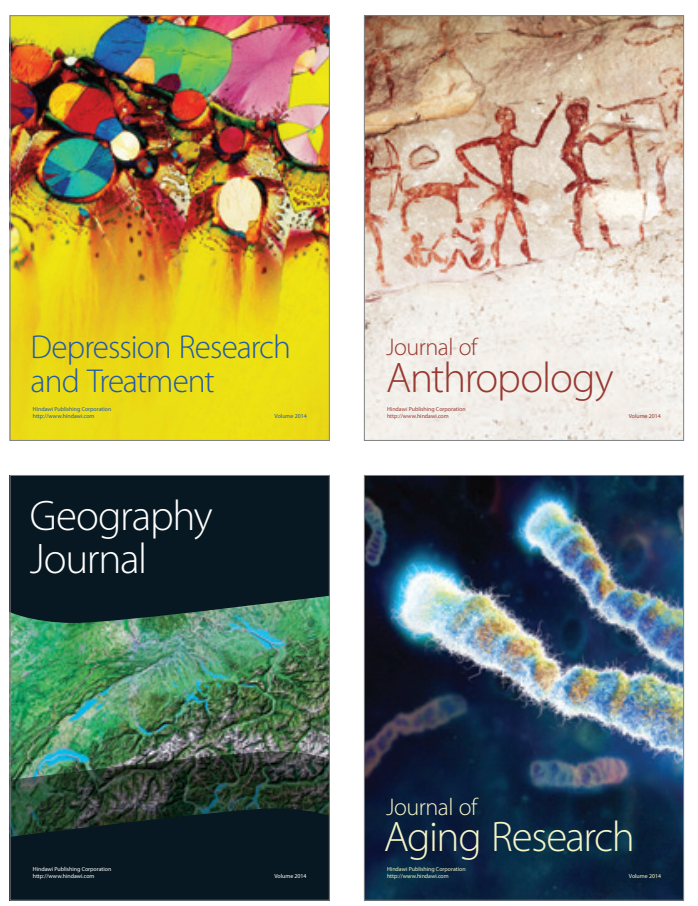
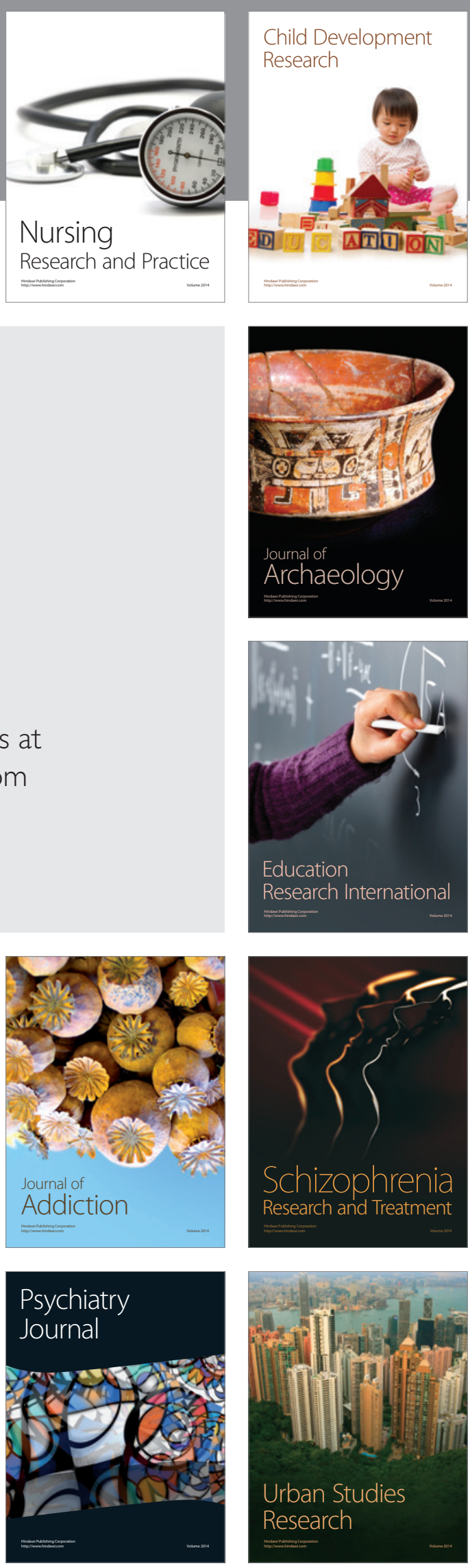